Peer-Reviewed Article

ISSN: 2162-3104 Print/ ISSN: 2166-3750 Online Volume 7, Issue 4 (2017), pp. 990-1009 (C) Journal of International Students http://jistudents.org/ doi: 10.5281/zenodo. 1035953

\title{
International Students' Cocurricular Involvement at a University in South Africa
}

\author{
Sapna Naik \\ Michigan State University, USA \\ Matthew R. Wawrzynski \\ Michigan State University, USA \\ Joelle Brown \\ Indiana University, USA
}

\begin{abstract}
Despite a growing body of literature on international student involvement, international students in the South African context have remained understudied. In this quantitative study, we examined international students' cocurricular involvement and associated learning and development in a South African university. Participants included 198 international students who completed the Student Experiences Survey (SES). We found international students were generally highly involved and reported benefits and barriers to their involvement as well as a strong sense of belonging. Recommendations to better integrate international students into the university by minimizing barriers and increasing opportunities and learning in involvement are included for student affairs practitioners.
\end{abstract}

Keywords: cocurricular involvement, international students, South Africa, student engagement 
$\mathbf{O}_{\text {ver }} 4$ million international students enroll each year in colleges and universities across the world, which represents a $100 \%$ increase since 2000 (World Education Services, 2014). Akin to other systems of higher education, South Africa continues to experience an increase of international students enrolling in its colleges and universities. The Council of Higher Education (CHE, 2016) in South Africa noted the number of its international undergraduate students increased from 50,000 to 70,000 over a decade starting in 2003, as did the percent of postgraduate international students, which increased from $10 \%$ in 2002 to $14 \%$ in 2012. Most international students in South Africa come from sub-Saharan Africa (UNESCO Institute for Statistics [UIS], 2016), making South Africa an important regional hub (Lee \& Sehoole, 2015). Yet, despite the increased enrollment of international students worldwide, most of the research on international students is on those studying in the U.S., Australia, and U.K. Simply put, very little is known about international student experiences in their host countries and specifically for our study, South Africa. When researchers have studied experiences of international students in South African universities, it is often within curricular settings, such as of Chinese international students as English language learners (Ayliff \& Wang, 2006), or theoretically exploring challenges international students face (Dominguez-Whitehead \& Sing, 2015).

Moreover, recent events in South Africa including xenophobic attacks based on the belief that international students are taking admission slots from Black South Africans (Sehoole, 2015) and recent \#FeesMustFall student protests (Da Silva, 2016) may create an unwelcoming environment for international students in South Africa. Given the importance of international students to South African universities' diversity and finances, ensuring positive learning outcomes is critical. One mechanism for promoting these outcomes is through student engagement (Strydom, Kuh, \& Mentz, 2010), which includes a variety of cocurricular activities often supported by student affairs and services. Indeed, Schreiber (2014) argues in addition to a student engagement role, student affairs has a role in equalizing participation for all students. Furthermore, international students are an important component of the student body who must be given equal opportunities to participate in higher education.

Existing research, however, has failed to examine the cocurricular experiences of international students in many contexts, and specifically in our study, South Africa. Therefore, the findings from our study address at 
least three gaps in the extant international student literature. First, we seek to begin to fill the gap in the literature on international students' cocurricular experiences in South Africa. Second, we advance a more culturally relevant framework beyond those based on Western students and contexts. Third, we provide implications for student affairs practice and various functional areas focused on inclusive practices for international students and their successful transition into the university.

Thus, we aim to answer the following research questions: (1) What are the characteristics (country of origin, sex, living status, academic discipline and level, finance) and patterns of cocurricular involvement of international students at South African University (SAU) (a pseudonym)? (2) What learning outcomes do international students derive from their involvement in cocurricular experiences? (3) What are the differences between involved and non-involved international students and among involved international students in characteristics, learning outcomes, and sense of belonging?

\section{LITERATURE REVIEW}

While there is little literature on international students involved in cocurricular experiences globally, there is an even greater dearth of literature on these students within South African universities. A majority of literature on international students is based on international enrollments in U.K., Australian, and U.S. contexts showcasing students from all over the world who matriculate to institutions in these countries. This literature often focuses on the culture shock that international students experience as they are coming from vastly different cultural environments (e.g., Newsome \& Cooper, 2016). In contrast, international students in South Africa largely come from Southern African Development Countries (SADC) (Lee \& Sehoole, 2015; UIS, 2016) making them a unique population who are most likely non-existent in other studies on international students. Although there are studies which broadly focus on cocurricular involvement within the South African context, they do not necessarily focus solely on international student populations (e.g., studies often compare international students to domestic students). For example, Wawrzynski, Heck, and Remley (2012) found several student outcomes such as leadership experience, career decision-making, and stress relief as a result of cocurricular involvement at a South African university. Both domestic and international students who were involved in cocurricular activities reported statistically significant 
greater student outcomes than students who were not involved (Wawrzynski et al., 2012). Furthermore, almost $80 \%$ of international students reported cocurricular involvement, which was higher than any domestic group (Wawrzynski et al., 2012), giving reason to study outcomes specifically for international students. Despite the uniqueness of the South African international student population, we draw upon existing studies on international students globally to provide a context for the types of learning outcomes that may be realized as a result of participation in cocurricular involvement.

In the U.S. context, leadership programs and community service activities are the most common forms of cocurricular involvement for international students, which students reported connected them to diverse sets of friends and helped them learn how to work together with others despite differences (Glass, Wongtrirat, \& Buus, 2015). Within the Australian context, one study found of the $50 \%$ of international students who were involved in organized campus activities, most were engaged in religious organizations (Rosenthal, Russell, \& Thomson, 2008). Across both the U.S. and Australian contexts, international students who participated in cocurricular activities were more likely to report engaging in the classroom more fully and feeling a strong sense of connection to their campus community (Glass, Buus, \& Braskamp, 2013; Rosenthal et al., 2008).

Since cocurricular activities influence student outcomes, student affairs practitioners who oversee these activities clearly can play a role in improving international student engagement. As a result of international student enrollment growth in post-apartheid South Africa, Rouhani (2007) examined internationalization of higher education. From this examination, Rouhani (2007) developed a six-phase model of internationalization, which involves institutions being proactive in the development of curriculum and student experience. One way student affairs professionals can operationalize this move toward proactivity is by creating an environment to foster international student involvement and success. One such proactive measure aligns with Schreiber's (2014) call for the role of student affairs in equalizing the opportunity for students from differing backgrounds to participate fully in educational experiences. In our study, we extend the existing literature by studying international student engagement through cocurricular activities specifically in the South African context to better understand how student affairs can improve participation with contextspecific data. 


\section{THEORETICAL FRAMEWORK}

Since much of student affairs literature in South Africa uses U.S.-based conceptual frameworks and models (e.g., Tinto's [1993] theory of student departure and Astin's [1985; 1993, 2002] I-E-O model), we sought to expand the use of other models and frameworks, which account for Afrocentric perspectives and contexts. Since almost all of the international students in our study came from the SADC, we argue Jama, Mapesela, and Beylefeld's (2008) circles of progression theory on student retention (see Figure 1) best frames the current study because it is more culturally relevant, and students coming from the SADC region are more similar to students in South Africa than those in Western countries. Also, the model was developed for non-traditional students, which Jama et al. (2008) define as "mostly Black students from disadvantaged family and school backgrounds" (p. 998), identifying financial constraints and language as frequent barriers to participation for these students.

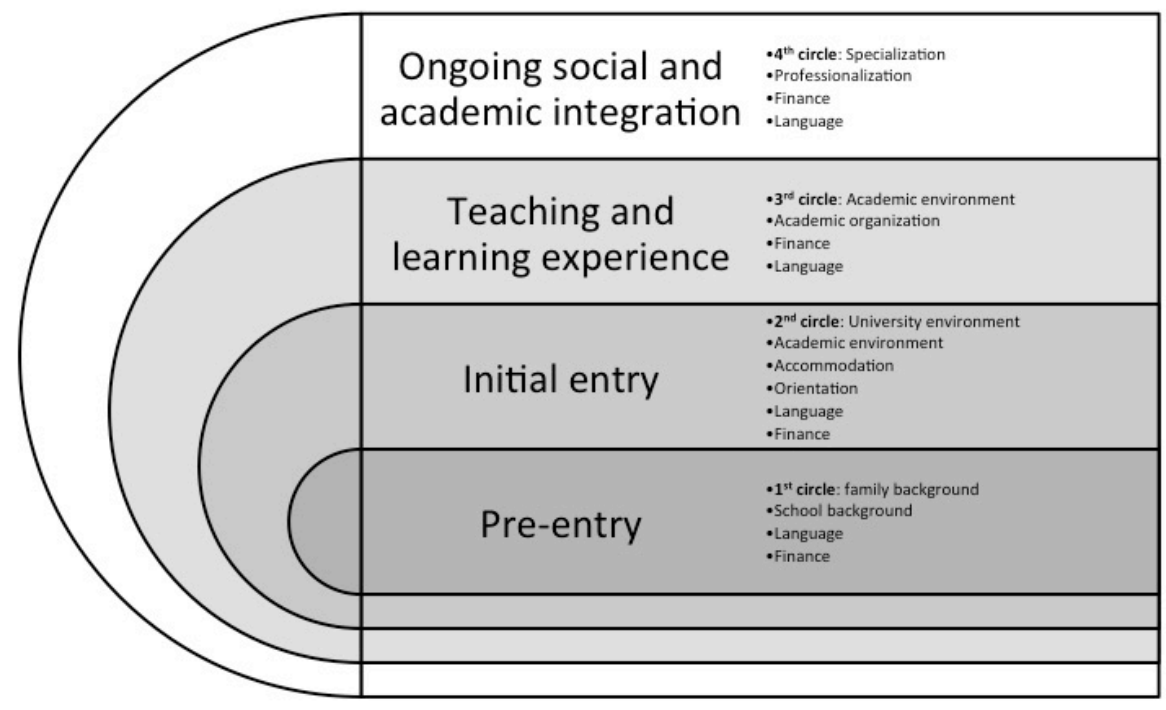

Figure 1. Adapted Circles of Progression Model of Student Retention (Jama, Mapesela \& Beylefeld, 2008, p. 999). 
Jama et al.'s (2008) circles of progression model consists of four circles describing students' progression through higher education institutions. The first of four circles in the theory identifies pre-entry characteristics and includes family background, language, and finance. The second circle, initial entry, includes activities that orient the student to the university. The third circle focuses on teaching and learning, and the fourth on ongoing social and academic integration. Jama et al.'s theory is suited to understand how cocurricular activities that integrate international students to the university interact with their background characteristics. As Jama et al. explain, their theory "provides a holistic understanding of the realities and challenges" (p. 1002) of students in the South African context. For the current study, we pay particular attention to various aspects of each of the four circles, namely family background, finance, university environment, academic environment, accommodation, and specialization. As the data were collected from a cross sample of students at the end of the academic year, the results are more likely to capture all of the stages of the model.

\section{METHOD}

Approximately 1500 international students at a large, comprehensive university (SAU) in South Africa's Eastern Cape were eligible to participate in a broader study, approved by authors' and host institution ethics research boards, to explore student cocurricular involvement, learning outcomes, and student characteristics. The data were collected using a two-pronged approach in November and December 2016 using the online Student Experiences Survey (SES) administered at SAU. The first prong included using a census approach where all eligible students were sent an email message via the university portal through which students access their email. The second approach consisted of having five students canvasing various on-campus (e.g., dining facilities, library, residence halls) and off-campus accredited accommodation locations with tablet computers because student access to computers is often limited, as many students do not own or have a regular access to computers.

The SES is a 60-item survey with five sections (i.e., sense of belonging, activity participation, outcomes, barriers, and demographics and characteristics). We established content validity after a review of the literature and through a collaborative process with members of the Cocurricular Forum and other campus stakeholders who served as South Africa content experts. In addition to several demographic questions we 
used the sentence stem (e.g., "As a result of my participation in cocurricular activities or experiences, I am able to") and the same response scale (1=strongly disagree to 5=strongly agree) to answer 24 Likert-type questions (e.g., "seek involvement with people different than me and/or with different points of view," "develop mutually beneficial relationships with others", or "identify personal strengths and growth areas"), which also aligned with institutionally identified outcomes for cocurricular involvement.

A majority of the international students were undergraduate students $(82 \%)$ and slightly more students were in their first year (33\%), 28\% were in their second year, $23 \%$ were in their third year, and $17 \%$ were in their fourth year; $94 \%$ were degree-seeking students, and $6 \%$ were exchange students; $57 \%$ identified as female; and three-fourths of students were 18 to 24 years old. Almost one-third were in the business and economics faculty, $28 \%$ were in health sciences or sciences, $17 \%$ were in engineering, $15 \%$ were in law, $8 \%$ were in arts, and $3 \%$ were in education. Almost two-thirds of the international students participated in cocurricular experiences and an equal number of students lived off campus with an average commute to campus being 24 minutes ( $S D=13.3$ minutes). Students came from 19 countries, but the countries where the greatest number of international students came from were Zimbabwe (41\%), Malawi (9\%), Zambia (8\%), Botswana (7\%), and Nigeria (6\%), consistent with origins of students across South Africa (UIS, 2016). Less than $1 \%$ of participants did not come from the African continent. Not surprising, as international students were not eligible for Ministry of Education bursary funding, most reported they relied on personal or family savings $(73 \%)$ as a main source of financing their education, $14 \%$ indicated sponsorship or scholarship, and only $7 \%$ indicated personal employment.

Since involvement in cocurricular experiences may lead to greater sense of belonging, we created a sense of belonging composite variable (Cronbach alpha $=.82$ ) consistent with other research using three survey questions: "I feel a sense of connection with SAU," "I am proud to be attending SAU," and "I feel like SAU is a community."

Although the current study advanced literature on international student cocurricular involvement, there are several notable limitations. First, most of the international students who participated in the study came from the SADC region, making the study limited in its generalizability to other international contexts. Second, although we intentionally increased our efforts to recruit a sample representative of international students at SAU, 
our sample was not random as we used a census approach. We had a slightly greater proportion of on-campus international students complete the survey. Third, a period of data collection took place when the campus was shut down over Fees Must Fall protests, which may have limited participation by more international students.

\section{RESULTS}

In addition to international students' demographics, we explored their patterns of involvement to answer the first research question using descriptive statistics and frequencies. We found the most common type of involvement were in academic societies, with $50 \%$ of international students being involved, and religious societies, with over $40 \%$ of international students being involved. Among academic societies, students were most involved in Law Society, Golden Key International Honour Society, and the Industrial and Organizational Psychology Society. Over 20\% were involved in sports, with soccer and swimming being most popular. Not surprisingly, many of the international students were involved in international student related organizations, including the International Student Society, Zimbabwe Society, and Botswana Society. Politically, students indicated involvement in the Democratic Alliance Student Organisation (DASO), consistent with international students becoming involved with political activism in South Africa (Habib, 2017). One third of those involved participated in residence events. Finally, a third of involved students held leadership roles in their organizations.

To answer the second research question on learning outcomes derived from participation, we again used descriptive statistics and frequencies and found involved international students agreed to strongly agreed with developing skills for all of the learning outcomes as a result of participating in cocurricular activities (average range of 3.94 to 4.30). Among the most agreed upon outcomes were "listen attentively to others," "take responsibility for my actions," and "understand personal strengths and growth areas." Among the least developed learning outcomes were those aligned with career development, managing time effectively, and stress management.

The third research question used a number of statistical tests consistent with whether the independent and dependent variables were categorical or continuous data, after assessing if any assumptions would be violated during these analyses. We explored the differences between 
involved and non-involved international students and among involved international students in their characteristics, learning outcomes, and sense of belonging. Using Chi-square with our categorical data, we found a statistically significant greater percentage of on-campus international students, $\chi^{2}(1, n=198)=7.07, p=.01, \phi=.20$, were involved in cocurricular experiences than were their off-campus peers, which is consistent with other studies examining students on-campus and off-campus participation (Wawrzynski et al., 2012). The overall effect on involvement was a medium to small association with whether students lived on-campus or off-campus. Interestingly, $8 \%$ of students who lived off-campus still participated in residence events.

\section{Table 1: Barriers to Cocurricular Involvement by Participation}

\begin{tabular}{ccccc}
\hline \multicolumn{4}{c}{ Actual Involvement } & \\
$\%$ Yes & $\%$ No & $\chi^{2(1)}$ & $\phi$ \\
$(n=125)$ & $(n=73)$ & & \\
$\%$ & $n$ & $\%$ & $n$ & \\
\hline
\end{tabular}

Barriers to Involvement

Day and times that the activity is held

Yes

$74 \quad 9$

26

$16.75^{*} \quad .30$

Lack of knowledge of activities

Yes

$\begin{array}{llllll}47.8 & 2 & 52.2 & 2 & 5.20^{*} & -.18 \\ & 2 & & 4 & & \end{array}$

Time (involvement in other activities)

Yes

$\begin{array}{lllll}70.9 & 7 & 29.1 & 3 & 4.86^{*}\end{array}$

Note. (1) $p \leq .05$

When we explored the categorical potential barriers to involvement variables, using Chi-square, we found three of the barriers to be statistically significant with medium to small associations. With one barrier, a greater percentage of international students' lack of involvement was due to not knowing about the activities $\chi^{2}(1, n=198)=5.20, p=.02, \phi=-.18$. We found, however, international students who were involved were more likely to report as barriers to their involvement the following: time and day activities were held $\chi^{2}(1, n=198)=16.75, \mathrm{p}=.00, \phi=.30$ and involvement in other activities, $\chi^{2}(1, n=198)=4.86, p=.02, \phi=.17$. We only report statistically significant results. See Table 1. 
When we explored the categorical variables barriers and sex using Chi-square, we found a greater percentage of female than male students reported their job interfered with their involvement levels $\chi^{2}(1, n=198)=$ $6.32, p=.01, \phi=.20$. Although we explored other analyses, we found no statistically significant percentages for international students in various faculties; however, we noted international students in arts, business and economics, engineering, and sciences had lower participation in cocurricular experiences than did international peers in other faculty (e.g., health sciences and law).

When we explored differences between the categorical variables sex and the continuous learning outcome variables for those involved using independent samples t-tests, we found male $(M=4.34, S D=.63)$ and female $(M=4.04, S D=.81)$ international students agreed to strongly agreed they developed learning outcomes as a result of participation in cocurricular activities and experiences. However, only ability to "seek involvement with people different than me and/or with different points of view" was statistically significant $\left(t(120)=-2.287, p=.03, \eta^{2}=.04\right)$ between males and females with males being slightly more likely to strongly agree. Using guidelines by Cohen (1988), there was a moderate to small effect with sex explaining $4 \%$ of the variance between sex and the learning outcomes. In other words, one's sex influenced the outcome "seek involvement with people different than me and/or with different points of view."

When we examined reported gains in participation by the categorical academic class year variable using ANOVA, only the continuous variable "actively engage in my community to work for positive change" was statistically significant. This finding suggests third year international students were more likely than first, second, or fourth year international students to strongly agree with this outcome as a result of participation in cocurricular activities. This finding resulted in $11 \%$ of the variance in "actively engage in my community to work for positive change" due to class year. The finding aligns with both the movement through the four stages of Jama et al.'s (2008) circles of progression model and the likely time to degree completion for SAU students. Agreement with this outcome in the fourth year might be lower because it may reflect students who are taking longer to complete the degree. See Table 2 for complete results. 
Table 2: Actively Engage In My Community To Work For Positive Change By Class Year

$\begin{array}{cccccc}\begin{array}{c}\text { First Year } \\ (n=65)\end{array} & \text { Second } & \text { Third } & \text { Fourth } & \text { Sig* }^{*} & \eta^{2} \\ & \text { Year } & \text { Year } & \text { Year } & & \\ & (n=55) & (n=45) & (n=33) & & \end{array}$

\begin{tabular}{lcccccccccc}
\hline & $M$ & $S D$ & $M$ & $S D$ & $M$ & $S D$ & $M$ & $S D$ & & \\
\hline Actively engage & 3.79 & 1.02 & 3.86 & .81 & 4.55 & .63 & 3.75 & 1.25 & $1 \mathrm{v} .3$ & .11 \\
in my & & & & & & & & & $2 \mathrm{v} .3$ & \\
$\begin{array}{l}\text { community to } \\
\text { work for } \\
\text { positive change }\end{array}$ & & & & & & & & & $4 \mathrm{v} .3$ & \\
& & & & & & & & & & \\
\hline
\end{tabular}

Note. ${ }^{*} p<.05 ; F(3,118)=4.821, p=.003 ; 1=$ strongly disagree to $5=$ strongly agree

We ran a series of ANOVAs and explored the differences in the continuous learning outcome variables for those international students who were involved in cocurricular experiences to those who held leadership positions within the curricular experiences. Again, while all involved students agreed to strongly agreed with outcomes associated with their involvement, those in leadership positions reported statistically significant findings for four of our dependent variables. See Table 3 for complete results.

In our final analyses we examined differences in international student characteristics and sense of belonging using independent samples ttests or ANOVAs when appropriate. We did not find statistically significant differences between involved and noninvolved students and among involved international students. For example, no differences were found between international students involved in cocurricular experiences and those in leadership positions within the cocurricular experiences to sense of belonging, perhaps because both groups generally reported relatively strong measures in sense of belonging (i.e., involved $M=11.46, S D=2.57$; not involved $M=11.21, S D=3.01$ ). 
Table 3: Involved in Cocurricular Experience and Leadership Role by Learning Outcomes for Involvement

\begin{tabular}{|c|c|c|c|c|c|}
\hline & \multicolumn{2}{|c|}{$\begin{array}{c}\text { Leadership } \\
\text { yes } \\
(n=37)\end{array}$} & \multicolumn{2}{|c|}{$\begin{array}{c}\text { Leadership } \\
\text { no } \\
(n=86)\end{array}$} & \multirow[t]{2}{*}{$\eta^{2}$} \\
\hline & $M$ & $S D$ & $M$ & $S D$ & \\
\hline $\begin{array}{l}\text { respond to challenges, transitions, } \\
\text { and new situations more openly*a }\end{array}$ & 4.24 & .68 & 3.94 & .71 & .04 \\
\hline $\begin{array}{l}\text { seek to negotiate and balance diverse } \\
\text { views to reach a workable solution*b }\end{array}$ & 4.27 & .73 & 3.97 & .74 & .04 \\
\hline $\begin{array}{l}\text { think creatively to generate new } \\
\text { ideas and innovations }{ }^{* c}\end{array}$ & 4.24 & .76 & 3.97 & .71 & .03 \\
\hline $\begin{array}{lll}\text { effectively } & \text { facilitate } & \text { group } \\
\text { discussions*d }\end{array}$ & 4.24 & .76 & 3.92 & .76 & .04 \\
\hline
\end{tabular}

\section{DISCUSSION}

South Africa is an important regional hub, meaning most international students come from Southern African countries, and more specifically the SADC region, which is consistent with the sample of international students at SAU in our study. This finding adds to a growing body of literature on international students, which is often dominated by studies on international students who come from China and India and enroll in U.S., U.K., and Australian colleges and universities. Our results offer support for the use of more culturally relevant frameworks such as Jama et al.'s (2008) circles of progression model to examine international students' cocurricular involvement, but the framework could expand its definitions and terms to better capture the realities of international students in South Africa. We also found most international students at SAU were degree-seeking and financed their education through personal and family savings.

In terms of international student involvement, we did find some consistencies with previous studies. Another study in the South African context found high involvement among international students (Wawrzynski et al., 2012). High involvement in religious societies was found in the Australian context (Rosenthal et al., 2008), and international students were often involved in leadership as in the U.S. context (Glass et al., 2013). Another finding that adds to the growing body of international student 
literature is our finding on high levels of involvement in internationallyoriented organizations by international students in our study.

Our second research question revealed international students did report gains in learning outcomes as a result of their participation in cocurricular activities. Such a finding adds to the literature about international students and their cocurricular involvement, indicating learning is taking place from these experiences. This finding confirms students' progression from one stage to the next in Jama et al.'s (2008) circles of progression model. As Jama et al. explain, what students learn in one stage must be applied and supports learning in the next stage.

The third research question explored differences between involved and non-involved international students at SAU. First, we found on-campus students were more likely to be involved, which is consistent with Wawrzynski et al. (2012) who found on-campus domestic students in South Africa were more likely to be involved in cocurricular activities. We found non-involved students were more likely to report lack of knowledge of activities as a barrier to their involvement, whereas involved international students were more likely to report day and time of activities and involvement to other activities as barriers to their involvement. This finding suggests although international students identified these two barriers to involvement they were still involved, which suggests greater involvement could be realized if the barriers were eliminated. Although Jama et al. (2008) focused on barriers of finance and language as inhibiting students' progression in their model, we found additional barriers that influence participation of international students. Jama et al.'s framework could incorporate these additional barriers to more comprehensively show the realities of higher education experiences for international students in the South African context.

In terms of learning outcomes, we found few statistically significant differences, specifically between males and females on ability to "seek involvement with people different than me or with different points of view," and third year students reporting most likely to strongly agree with "actively engage in my community to work for positive change." We also found students in leadership positions reported higher outcomes on four learning outcomes. When comparing to Western literature on international students, however, we consider there may be differing definitions of leadership. In the South African context, leadership is based in Ubuntu, the concept of "I am because we are," which emphasizes connection to the community (Msila, 2008). 
In contrast with the sense of belonging literature in the U.S. (e.g., Glass et al., 2013), we found there were no statistically significant differences between students involved and not involved in terms of their sense of belonging with the university. All international students reported a relatively high sense of belonging with SAU. Perhaps because of their significant investment in their higher education in South Africa, international students feel a strong sense of belonging with the institution. Another reason for this finding may be due to their reporting high levels of sense of belonging in an effort to feel more connected to the university. For example, Soudien (2008) explains in the post-apartheid South African context, the desire to fit in for previously marginalized students can result in more positive reporting on sense of belonging on institutional surveys.

Our findings also extend existing understandings of international students in the literature. Such findings advance the need for culturally relevant frameworks, such as Jama et al. (2008) to explain students' progression from initial entry through integration in a university in South Africa. Results also affirm the need to further understand international students' cocurricular experiences and outcomes. In addition to adding to the literature on international students, we offer implications for practice and future research.

\section{IMPLICATIONS FOR PRACTICE}

The purpose of our study was to add to an understanding of the experiences of international students in the context of South African higher education. To align with Strydom and Mentz's (2013) call for empirical research to shape practices, results from this study can influence practices to better recruit and retain international students at SAU and other South African universities. The aim to improve student affairs practices for international students is of particular importance given the current political climate may shape the experiences of international students. Although international student enrollment continues to rise across the globe (de Wit, 2017), antiimmigrant sentiments could influence the quality of international students' experiences, in the South African and other contexts. Our findings do not appear to show an effect of the current political climate upon the experiences of international students at SAU as international students reported high agreement with statements on their sense of belonging. However, consistent with Rouhani's (2007) call to be proactive and Schreiber's (2014) call for the equalizing role of student affairs, we argue 
student affairs and engagement could alleviate potential influences of antiimmigrant sentiments in South Africa.

Our results show although international students are involved in cocurricular activities, mere involvement is not enough to ensure positive learning outcomes. Higher education institutions thus can take action to guide learning in cocurricular activities. We offer several recommendations for practice based on our results.

First, advertising of cocurricular activities and their benefits must begin at orientation and continue throughout students' college experience. As Jama et al. (2008) explain, initial entry is an important phase of socialization for students in the South African context. International students who are involved all reported important gains in learning outcomes; therefore student affairs practitioners can encourage involvement early when they first get to campus, consistent with Jama et al.'s second phase of progression. If students receive multiple messages about the benefits of cocurricular activities from the time they arrive on campus, it will help them to move through the model, to potentially align with components of the circles of progression model. In addition, as non-involved students were most likely to indicate a lack of knowledge of activities was a barrier to their involvement, student affairs officers have an opportunity to advertise the existence of activities as well as the benefits, through multiple means of communication (e.g., SMS, email, social media).

Second, student affairs officers can encourage academic advisors and faculty members to take a greater role in informing their students of the existence and benefits of cocurricular involvement in supplementing their studies. Faculty can integrate the experiences into the classroom, so students see a more seamless college environment, which has the potential to lead to greater gains in student development and learning. Furthermore, student affairs can partner with faculty to integrate cocurricular engagement into academics making activities part of the learning experience rather than in addition to, alleviating issues of time, which students in our study reported as barriers to involvement. Evening activities may be inaccessible to many students who have long commute times and during which transportation options are limited. Some institutions, like SAU, have designated lunch periods, so faculty could utilize this common lunch hour as a time for cocurricular activities to take place allowing activities to be integrated into times students are already on campus. Such faculty partnership with student affairs solves two issues our study found. First, faculty are encouraging participation and encouraging students to become aware of activities, and 
second, it alleviates some of the barriers to involvement by making cocurricular involvement more accessible.

Third, as a third of international students live on-campus, and even some off-campus residents participate in residence events, housing staff have opportunities to involve students and integrate learning outcomes into residence hall activities. In addition, off-campus accredited housing, which function in a similar manner to on-campus housing, can further encourage students to become involved. On-campus activities in residence halls also minimize time and transportation as potential barriers to participation. Rethinking the time and locations events are offered can make them more accessible for students. Housing staff can utilize designated lunch hours and other times students are on campus to allow students to participate in cocurricular activities.

Fourth, student affairs professionals can work to align desired learning outcomes with activities within cocurricular experiences. For instance, if career development is a desired goal, then cocurricular experiences should be intentionally designed to include career development. At SAU, officials have made a concerted effort to use cocurricular activities as a means to develop skills that employers identify for students as necessary for employment upon degree completion. Skill development through cocurricular activities is particularly important for international students who are likely to have restrictions on working while earning their degree.

Fifth, as we found those international students involved in leadership roles reported greater gains in learning outcomes, student affairs staff should seek opportunities to integrate leadership development activities into the larger goals of student organizations. For even greater gains among student leaders, for example, student affairs staff should create training experiences for student leaders to help student leaders reach desired learning outcomes and skill development. Developing skills and learning through leadership training can help support SAU's effort to give students opportunities to build desirable skills for employers to take the place of hard-to-reach employment opportunities.

\section{IMPLICATIONS FOR FUTURE RESEARCH}

Several questions are left to be explored to better understand international students' cocurricular experiences in the South African context as well as globally. First, an interesting finding is international students who are not 
involved perceive benefits to involvement and are likely to lack knowledge about the activities. Our data do not reveal why some international students who perceive there would be benefits to involvement might still remain uninvolved once they learn about the activities; therefore, future research should explore the reasons international students may remain uninvolved in cocurricular activities. Second, future research could explore the differences between involvement and learning among international students and domestic students in the South African context. Third, from a student affairs research standpoint, researchers could explore the mechanisms by which students can learn about the existence and benefits of cocurricular involvement, including the culturally relevant mediums that students use to communicate and learn about information. In the South African context, for example, students often use SMS as a means to communicate. Therefore, student affairs could explore how best to communicate with students using technology often used and preferred by students. Fourth, future research could work specifically from Jama et al.'s (2008) model to better understand how students progress from one circle of the model to the next. Such an understanding would better enable student affairs to focus their efforts to making sure students progress through the circles representing entry to academic and social integration. Finally, the data collection took place when SAU was temporarily shut down due to student protests over Fees Must Fall. We are unsure about the implications the protests had or will continue to have on the sense of belonging, participation, and quality of experiences of international students. Future iterations of the survey as well as additional research can explore the implications of environmental factors, which may affect student learning (e.g., student protests, rising fees), upon international student experiences in South Africa.

\section{CONCLUSION}

The current study adds to the growing body of literature on international students in higher education institutions across the world, and specifically, in South Africa. We aimed to better understand an understudied aspect of international students in South Africa, namely, their cocurricular involvement, using a culturally relevant theory, Jama et al.'s (2008) circles of progression model of student retention. More specifically, we examined international students' characteristics and patterns of cocurricular involvement, learning outcomes as a result of their participation, and differences among international students in their involvement. We found, in 
our study, international students are highly involved in cocurricular experiences, agree that they learn from those experiences, and report high levels of sense of belonging. Differences were found among male and female international students, students in the third year of study, and among those who held leadership roles. We also found students reported barriers of day and time, involvement in other activities, and lack of knowledge of activities. The findings add to Jama et al.'s inclusion of finance and language as barriers. Many practical implications for student affairs and functional areas emerge from the results. Specifically, orientation, faculty, and residence life can all learn from the findings to educate students about cocurricular activities and minimize barriers to their participation. Furthermore, student affairs should be intentional about the desired outcomes and tailor activities accordingly for student leaders and all involved students. Future research can further explore mechanisms that allow students to progress in Jama et al.'s model from one stage to the next as well as ways that student affairs can communicate to students the existence and benefits of cocurricular involvement to international students.

\section{REFERENCES}

Astin, A. W. (1985). Student involvement: A developmental theory for higher education. Journal of College Student Personnel, 25, 297-308.

Astin, A. W. (1993). What matters in college? Four critical years revisited. San Francisco, CA: Jossey-Bass.

Astin, A. W. (2002). Assessment for excellence. Westport, CT: Oryx Press.

Ayliff, D., \& Wang, G. (2006). Experiences of Chinese international students learning English at South African tertiary institutions. South African Journal of Higher Education, 20(3), 25-37.

Cohen, J. (1988). Statistical power analysis for the behavioral sciences. Hillsdale, NJ: Lawrence Earlbaum.

Council on Higher Education. (2016). 2013 Higher education data: Participation. Retrieved from http://www.che.ac.za/focus_areas/higher_education_data/ 2013/participation

Da Silva, D. (2016, October 17). What happens to international students during fees must fall? The Daily Fox. Retrieved from http://www.thedailyvox.co.za/ happens-international-students-fees-must-fall/

De Wit, H. (2017, February 24). Internationalisation of HE may be accelerating. University World News, 448. Retrieved from 
http://www.universityworldnews.com/article.php?story=201702202323422 76

Dominguez-Whitehead, Y., \& Sing, N. (2015). International students in the South African higher education system: A review of pressing challenges. South African Journal of Higher Education, 29(3), 77-95.

Glass, C. R., Buus, S., \& Braskamp, L. A. (2013). Uneven experiences: What's missing and what matters for today's international students. Chicago, IL: Global Perspective Institute.

Glass, C. R., Wongtrirat, R., \& Buus, S. (2015). International student engagement: Strategies for creating inclusive, connected, and purposeful campus environments. Sterling, VA: Stylus.

Habib, A. (2017, March 13). [Featured speaker.] Presentation at NASPA, San Antonio, TX.

Jama, M. P., Mapesela, M. L. E., Beylefeld, A. A. (2008). Theoretical perspectives on factors affecting the academic performance of students. South African Journal of Higher Education, 22(5), 992-1005.

Lee, J. J., \& Sehoole, C. (2015). Regional, continental, and global mobility to an emerging economy: The case of South Africa. Higher Education, 70, 827843.

Msila, V. (2008). Ubuntu and school leadership. Journal of Education: Periodical of the Kenton Education Association, 44, 67-84.

Newsome, L. K., \& Cooper, P. (2016). International students' cultural and social experiences in a British university: "Such a hard life [it] is here." Journal of International Students, 6(1), 195-215.

Rosenthal, D. A., Russell, J., \& Thomson, G. (2008). The health and wellbeing of international students at an Australian university. Higher Education, 55, 51-67.

Rouhani, S. (2007). Internationalisation of South African higher education in the postapartheid era. Journal of Studies in International Education, 11(3/4), 470-485.

Schreiber, B. (2014). The role of student affairs in promoting social justice in South Africa. Journal of College \& Character, 15(4), 211-218.

Sehoole, C. (2015, May 21). International students love South Africa, but xenophobia could be a heartbreaker. The Conversation. Retrieved from http://theconversation.com/international-students-love-south-africa-butxenophobia-could-be-a-heartbreaker-41707

Soudien, C. (2008). The intersection of race and class in the South African university: Student experiences. South African Journal of Higher Education, 22(3), 662-678.

Strydom, F., Kuh, G., \& Mentz, M. (2010). Enhancing success in South Africa's higher education: Measuring student engagement. Acta Academia, 42(1), 259-278. 
Strydom, J. F., \& Mentz, M. (2013). Enhancing a culture of evidence: Using student engagement to identify problem areas which institutions can do something about. South African Journal of Higher Education, 27(2), 401-418.

Tinto, V. (1993). Leaving college: Rethinking the causes and cures of student attrition ( $1^{\text {st }}$ ed.). Chicago, IL: University of Chicago Press.

UNESCO Institute for Statistics (UIS). (2016). Global flow of tertiary-level Students. Retrieved from http://www.uis.unesco.org/Education/Pages/ international-student-flow-viz.aspx

Wawrzynski, M. R., Heck, A. M., \& Remley, C. T. (2012). Student engagement in South African higher education. Journal of College Student Development, 53(1), 106-123. doi:10.1353/csd.2012.0007

World Education Services. (2014, October). International student mobility trends. Retrieved from http://www.wes.org/wes40forum/internationalstudent factsheet.pdf

SAPNA NAIK, M.Ed., is a doctoral student in the Higher, Adult, and Lifelong Education program at the College of Education at Michigan State University. Her research focuses on the experiences of international students. Email: naiksapn@msu.edu

MATTHEW R. WAWRZYNSKI, PhD, is associate professor and director for the Higher, Adult, and Lifelong Education program at Michigan State University. His research focuses on the college environment and its influence on learning and outcomes. Email: mwawrzyn@msu.edu

JOELLE BROWN, MA, is a scholar advisor in the Office of International Services at Indiana University. She was a master's student in Michigan State University's Student Affairs Administration program while working on this study. Email: jobrow@iu.edu 